\title{
Predictive Value of Cell Assays for Developmental Toxicity and Embryotoxicity of Conazole Fungicides
}

\author{
Karin Dreisig, Camilla Taxvig, Mia Birkhфj Kjorstad, Christine Nellemann, Ulla Hass, \\ and Anne Marie Vinggaard
}

National Food Institute, Technical University of Denmark, Søborg, Denmark

\begin{abstract}
Summary
This paper evaluates in vivo predictability of a battery of in vitro tests covering developmental toxicity and embryotoxicity of five widely used conazole fungicides. The conazoles were investigated in the embryonic stem cell test, and data were compared to in vivo embryotoxicity data. The same conazoles were evaluated on the basis of data from a battery of cell assays for endocrine activity, including assays for AR, ER, AhR, and sex hormone synthesis, and data were compared to in vivo developmental toxicity data. Overall, the ranking of the five conazole fungicides based on in vitro data were in reasonably good agreement with available in vivo effects. Ketoconazole and epoxiconazole are the most potent embryotoxic compounds, whereas prochloraz belongs to the most potent developmental toxicants. In conclusion, a rough prediction of the ranking of these conazole fungicides for in vivo toxicity data was possible by a holistic evaluation of data from a panel of cell-based assays.
\end{abstract}

Keywords: conazole fungicide, developmental toxicity, embryotoxicity

\section{Introduction}

Toxicology faces a great challenge as humans are exposed to large numbers of chemicals for which we lack toxicological information. The lack of toxicity data calls for new approaches. Some see the future in the strength of in vitro and in silico methodologies based on human material in which pathways of toxicity can be elucidated and evaluated by a holistic approach. Apart from convincing scientific visions and arguments, a variety of other good reasons exist for promoting the development of cell-based alternatives to animal testing. These include important political, ethical, as well as economic reasons. In 2013 the final ban on using animals to test ingredients for cosmetics in the EU came into force although alternative methods are still lacking for various endpoints. REACH - the EU legislation on chemicals - requires comprehensive testing of many "old" substances. Performing this testing in animals would be time-consuming and costly and therefore alternative methods are needed. Pharmaceutical companies have a great interest to develop early, predictive toxicity tests for termination of problematic drug candidates early on.

Good case studies are needed to assess the predictability and value of in vitro tests. We have studied conazole fungicides in vitro and in vivo for a number of years and have compiled the data for the purpose of retrospectively evaluating the predictive potential of in vitro tests in terms of developmental toxicity and embryotoxicity. In this paper we have assessed the embryotoxic potential in vitro of five conazole fungicides and compared these and other in vitro results to our own and other published data from in vivo developmental animal studies.

Imidazoles and triazoles currently are used worldwide as fungicides for grain, vegetables, fruit, and flower production and as pharmaceuticals for treatment of human mycoses (Kjaerstad et al., 2010b). Their pharmacological action is based on the binding and inhibition of the enzyme lanosterol-14- $\alpha$-demethylase (CYP51) that converts lanosterol to ergosterol in fungal cell membranes (Giavini and Menegola, 2010). However, CYP inhibitory ability of these compounds is not limited to this enzyme or to fungi. Some conazole fungicides have been shown to influence the activity of other members of the CYP450 family, including key enzymes involved in the biosynthesis and metabolism of steroids in humans and animals. Two examples are $17 \alpha$-hydroxylase/17,20-lyase (CYP17) and aromatase enzyme (CYP19) that are responsible for the conversion of pregnenolone and progesterone to androgens and the conversion of androgens to estrogens, respectively (Kjaerstad et al., 2010a; Taxvig et al., 2007; Vinggaard et al., 2000).

Beside interference with the CYP450 monooxygenases, conazole fungicides have been found to antagonize steroid hormone receptors such as the androgen (AR) and estrogen receptor (ER), along with an ability to activate the aryl hydrocarbon receptor (AhR) in cell assays (Vinggaard et al., 2000; Andersen

Received November 5, 2012; accepted in revised form January 23, 2013 
et al., 2002; Kjaerstad et al., 2007). Additionally, epoxiconazole and propiconazole gave rise to a weak estrogenic response in the MCF-7 cell proliferation assay (Kjaerstad et al., 2007). Taken together, this indicates that the conazoles might have multiple modes of action in regard to affecting reproductive development. Evidence for their adverse effects on development has been presented by rodent studies. Prochloraz, e.g., caused feminization and sexual malformations in male offspring after gestational and lactational exposure (Blystone et al., 2007; Vinggaard et al., 2005). Despite these known adverse effects, prochloraz was re-approved by the EU Commission in late 2011 after a short withdrawal, and it currently is approved for a wide variety of crops in the European Union (Muilerman et al., 2012).

Beside their effect on reproductive development, conazoles, including ketoconazole, epoxiconazole, and tebuconazole, have shown another toxicological potential in animal studies as they cause, e.g., increased embryolethality, cleft palate, reduced fetal weight, and axial skeleton malformations (Giavini and Menegola, 2010; Marotta and Tiboni, 2010). Human epidemiological studies on various azole antifungals found no associations between exposure to either triazole or imidazole substances during pregnancy (Marotta and Tiboni, 2010). However, Marotta and Tiboni (2010) state that these findings cannot be regarded as conclusive, given the methodological problems and limitations of the majority of the available human studies. Consequently, several triazoles and imidazoles, e.g., ketoconazole used for treatment of fungal infections were classified by the U.S. Food and Drug Administration, according to the risk in pregnancy, as category $\mathrm{C}$ (teratogenic or embryotoxic in animal studies without available reports or studies on humans). For this reason, the conazoles, used as drugs for systemic therapy against deepseated infections, extensive cutaneous diseases, and/or hair or nail mycosis are not recommended during the first trimester or during the pregnancy period in general, depending on the type of conazole fungicide (Menegola et al., 2006).

The cause of the teratogenic effect has been suggested to be another important group of enzymes believed to be inhibited by the conazoles, i.e., the CYP26 family. This family plays a crucial role in controlling endogenous retinoic acid (RA) levels in embryonic tissue. Imbalance in RA metabolism caused by triazoles has been demonstrated both in vitro and in vivo (Marotta and Tiboni, 2010). An increased level of endogenous RA was the suggested mechanism behind altered craniofacial morphogenesis such as cleft palate and reduced ossification of skull bones after in utero exposure to ketoconazole (Amaral and Nunes, 2008). Another possible mechanism for the developmental toxicity of conazole compounds might be via blocking of cardiac potassium channels. Chemicals blocking these channels cause malformations by a common embryonic cardiac arrhythmia/hypoxia mechanism (Danielsson et al., 2007). Recently, ketoconazole and other conazole compounds have been found to strongly inhibit cardiac potassium channels in neonatal rat ventricular myocytes (Sung et al., 2012) suggesting an alternative mode of action for the teratogenic effects of conazoles.

Overall, literature provides relatively comprehensive information on the in vivo effects of conazole fungicides in rodents.
In addition, there is fairly extensive in vitro information on the potential endocrine activity of these compounds. However, knowledge of embryotoxicity in vitro was lacking in order to perform a holistic evaluation of the predictability of in vitro assays for embryotoxicity as well as for developmental toxicity. Hence, in this paper we first investigated the embryotoxic potential of five conazole fungicides, i.e., epoxiconazole, ketoconazole, prochloraz, propiconazole, and tebuconazole in vitro using the embryonic stem cell test (EST). This assay currently is a promising approach to assess the embryotoxic potency of chemicals in vitro (Adler et al., 2008). It was developed to reduce animal use and represents an alternative test method for hazard assessment (Riebeling et al., 2011). A scientific validation by the European Center for the Validation of Alternative Methods (ECVAM) demonstrated that this test may be a reliable alternative or supplementary method to animal experiments testing for embryotoxicity. However, there is a need for further testing and evaluation of more chemicals by this method before it can be considered for regulatory acceptance and application (Genschow et al., 2002, 2004; Kuske et al., 2012; Marx-Stoelting et al., 2009). We gathered the available in vitro and in vivo information from literature with the aim of elucidating, retrospectively, whether we could have predicted developmental in vivo outcomes in animals from the selected battery of in vitro tests. Such information is important to learn from, as a future target is to design a panel of in vitro tests that can be used for predicting human toxic effects.

\section{Materials and methods}

\section{Principle of EST}

The principle and establishment of the EST has been described previously (Seiler et al., 2006). Briefly, two stable mouse cell lines were used: 1) an embryonic stem (ES) cell clone D3 to represent undifferentiated embryonic tissue and 2) $3 \mathrm{~T} 3$ fibroblasts to represent differentiated adult tissue. Suspension cultures of stem cells that spontaneously differentiate and form multicellular aggregates are referred to as embryonic bodies (EBs). Plating of the EBs allowed further differentiation and outgrowth, and the morphological assessment of contracting cardiomyocytes was used as an endpoint for differentiation (Seiler et al., 2006; Seiler and Spielmann, 2011). In order to predict the in vivo embryotoxic potential of a test compound a biostatistical model was applied (Seiler et al., 2006).

\section{Chemicals}

The following test compounds - all from Dr Ehrendorfer were used: epoxiconazole 99\% pure (CAS 106325-08-0, cat. EHRC 13185000), ketoconazole 99\% pure (CAS 65277-42-1, cat. EHRC14532000), prochloraz 99.6\% pure (CAS 67747-095 , cat. W16290000), propiconazole $97.5 \%$ pure (CAS $60207-$ 90-1, cat. EHRC16480000), and tebuconazole $98 \%$ pure (CAS 107534-96-3, cat. EHRC17178700). All test compounds were dissolved in dimethylsulfoxide (DMSO, Sigma, cat. D4540). Positive control was 5-fluorouracil (5-FU, CAS 51-21-8, Sigma, cat. F-6627) in DMSO. Negative control was penicillin G 
(PenG, CAS 69-57-8, Sigma, cat. A2058) in water. Cell medium solutions were constantly shaken during addition to plates in order to avoid precipitation.

\section{Cell culture}

Undifferentiated murine ES cells clone D3 (ATCC, cat. CRL1934) were cultured in humidified atmosphere at $37^{\circ} \mathrm{C}$ and $5 \% \mathrm{CO}_{2}$ in high-glucose Dulbecco's Modified Eagle's Medium (DMEM, Gibco, cat. 41965-039) containing 20\% heat-inactivated fetal calf serum (FCS, Hyclone, cat. A-1111-L), antibiotics $(50 \mathrm{U} / \mathrm{ml}$ penicillin and $50 \mu \mathrm{g} / \mathrm{ml}$ streptomycin, Invitrogen, cat. 15070-063), 1\% non-essential amino acids (NEAA, Gibco, cat. 11140-035), 2 mM L-glutamine (Gibco, cat. 25030-024), $0.1 \mathrm{mM} \beta$-mercaptoethanol (Sigma, cat. M7522). The cells were maintained in the presence of murine leukemia inhibitory factor (LIF, Sigma, cat. L5158-5UG) to inhibit spontaneous differentiation.

Balb/c 3T3 fibroblasts of type A31 (ATCC, cat. CCL-163) were cultured under similar conditions in high-glucose DMEM with $50 \mathrm{U} / \mathrm{ml}$ penicillin, $50 \mu \mathrm{g} / \mathrm{ml}$ streptomycin, $10 \%$ heat-inactivated FCS, and $4 \mathrm{mM} \mathrm{L-glutamine.}$

\section{EST differentiation assay}

The scientifically validated EST assay has been described in detail (Seiler et al., 2006). Briefly, suspensions of D3 cells in supplemented DMEM without LIF (3.75 x $10^{4}$ cells $\left./ \mathrm{ml}\right)$ were prepared for each concentration of the test chemical. $20 \mu \mathrm{l}$ cell suspension was placed as hanging drops on the lid of a bacterial Petri dish filled with $5 \mathrm{ml}$ phosphate buffered saline (PBS, OXOID, cat. BR0014g) and incubated for three days. During this period the cells aggregate to form EBs. After three days the EBs were transferred to a Petri dish with $10 \mathrm{ml}$ medium containing test concentration of each chemical and further cultivated as suspension culture for two days. On day five, separate EBs were plated into a 24-multiwell culture plate (Sarstedt, cat. 83.1835.300) containing $1 \mathrm{ml}$ medium/well with test compound. Differentiation was evaluated by microscopic inspection on day ten by determining the number of contracting cardiomyocytes in each well on each plate and comparing the number to the number of contracting EBs in the solvent control plate. Experiments were considered valid when 21 of 24 wells in the solvent control plate contained spontaneously beating cardiomyocytes. Interference with differentiation was evaluated at six test concentrations for each test compound between 4-128 $\mu \mathrm{M}$ in three independent experiments, except for tebuconazole, which was tested four times.

\section{Cytotoxicity assay}

Roughly, the cytotoxicity data is used to assess if stem cells are more sensitive to toxic agents than adult cells by determining the inhibition of growth of D3 and 3T3 cells. In the current study, cytotoxic effects on D3 and 3T3 were determined by applying the resazurin assay. $500 \mathrm{D} 3$ cells/well and 2,000 3T3 cells/well were allowed to attach during incubation for two hours in a black clear-bottomed 96-well plate (Biotech Line, cat. 3603) before adding medium with test compounds, the positive control, 5-FU, or the negative control, PenG. Cells were incubated until day ten with changes of medium containing test compound on days three and five. On day ten, a resazurin (Sigma, cat. 1770) solution in PBS was added directly to the wells for a final concentration of $2.5 \mu \mathrm{g}$ resazurin $/ \mathrm{ml}$ and incubated for three hours. Fluorescent signal was monitored using $560 \mathrm{~nm}$ excitation and $590 \mathrm{~nm}$ emission wavelength. Cytotoxicity of ketoconazole was tested in the concentration range 1.6-100 $\mu \mathrm{M}(\mathrm{n}=3)$ and for propiconazole, epoxiconazole, prochloraz, and tebuconazole in the concentration range 7.8-500 $\mu \mathrm{M}(\mathrm{n}=4)$.

\section{Statistics}

Three single endpoint values $(50 \%$ inhibition of cardiac cell differentiation (ID 50 ), 50\% viability of D3 cells ( $\mathrm{IC}_{50} \mathrm{D} 3$ ), and $50 \%$ viability of $3 \mathrm{~T} 3$ cells ( $\mathrm{IC}_{50} 3 \mathrm{~T} 3$ ) ) for differentiation and cytotoxicity were determined from dose-response-curves $(\mathrm{x}=\log (\mathrm{x}))$ using non-linear "Sigmoidal dose-response (variable slope)" fitted in GraphPad Prism 5. Constraints for bottom were between 0 and 100, and top was constant equal to 100 . A biostatistically-based prediction model (PM) that takes the three variables into account was applied to discriminate between three classes of embryotoxicity (non-embryotoxic, weakly embryotoxic, and strongly embryotoxic) as shown below. The PM for the EST has been described previously (Genschow et al., 2002, 2004).

Function I: $5.92 * \log \left(I C_{50} 3 T 3\right)+3.50 * \log \left(I C_{50} D 3\right)-5.31 *\left(\frac{I C_{50} 3 T 3-I D_{50}}{I C_{50} 3 T 3}\right)-15.7$
Function II: $3.65 * \log \left(I C_{50} 3 T 3\right)+2.39 * \log \left(I C_{50} D 3\right)-2.03 *\left(\frac{I C_{50} T 3-I D_{50}}{I C_{50} 3 T 3}\right)-6.85$
Function III: $-0.125 * \log \left(I C_{50} 3 T 3\right)-1.92 * \log \left(I C_{50} D 3\right)+1.50 *\left(\frac{I_{50} 3 T 3-I D_{50}}{I C_{50} 3 T 3}\right)-2.67$

Classification criteria

Class I: Non-embryotoxic if I $>$ II and I $>$ III

Class II: Weakly embryotoxic if II $>$ I and II $>$ III

Class III: Strongly embryotoxic if III $>$ I and III $>$ II

\section{Results and discussion}

Five conazole fungicides, three triazoles and two imidazoles, were tested for embryotoxic effects in the in vitro EST assay. The purpose was to evaluate how well the EST assay predicts the embryotoxic potential of conazole fungicides. The results, therefore, were compared to embryotoxicity in animals. Furthermore, we wanted to compare previously published in vitro data for endocrine activity with developmental toxicity outcomes from animal studies for the same fungicides.

EST endpoint values (ID50, IC50D3, and $\mathrm{IC}_{503} 3 \mathrm{~T} 3$ ) and their 95\% confidence intervals (95\% C.I.) were derived from the non-linear regression lines in Figure 1 and shown in Table 1. $\mathrm{IC}_{50}$ values for resazurin reduction were in the range of approximately $10-76 \mu \mathrm{M}$ and $25-132 \mu \mathrm{M}$ for D3 and 3T3 cells, respectively, and $50 \%$ inhibition of cardiac beating was found in the range of approximately 15-69 $\mu \mathrm{M}$ (Tab. 1). All five conazoles were classified as "weakly embryotoxic" when using the prediction model developed for the EST assay (Genschow et al., 2002, 2004).

The original EST has been expanded using, e.g., transcriptomics in ES cells or metabolomics of pluripotent human ES cells 


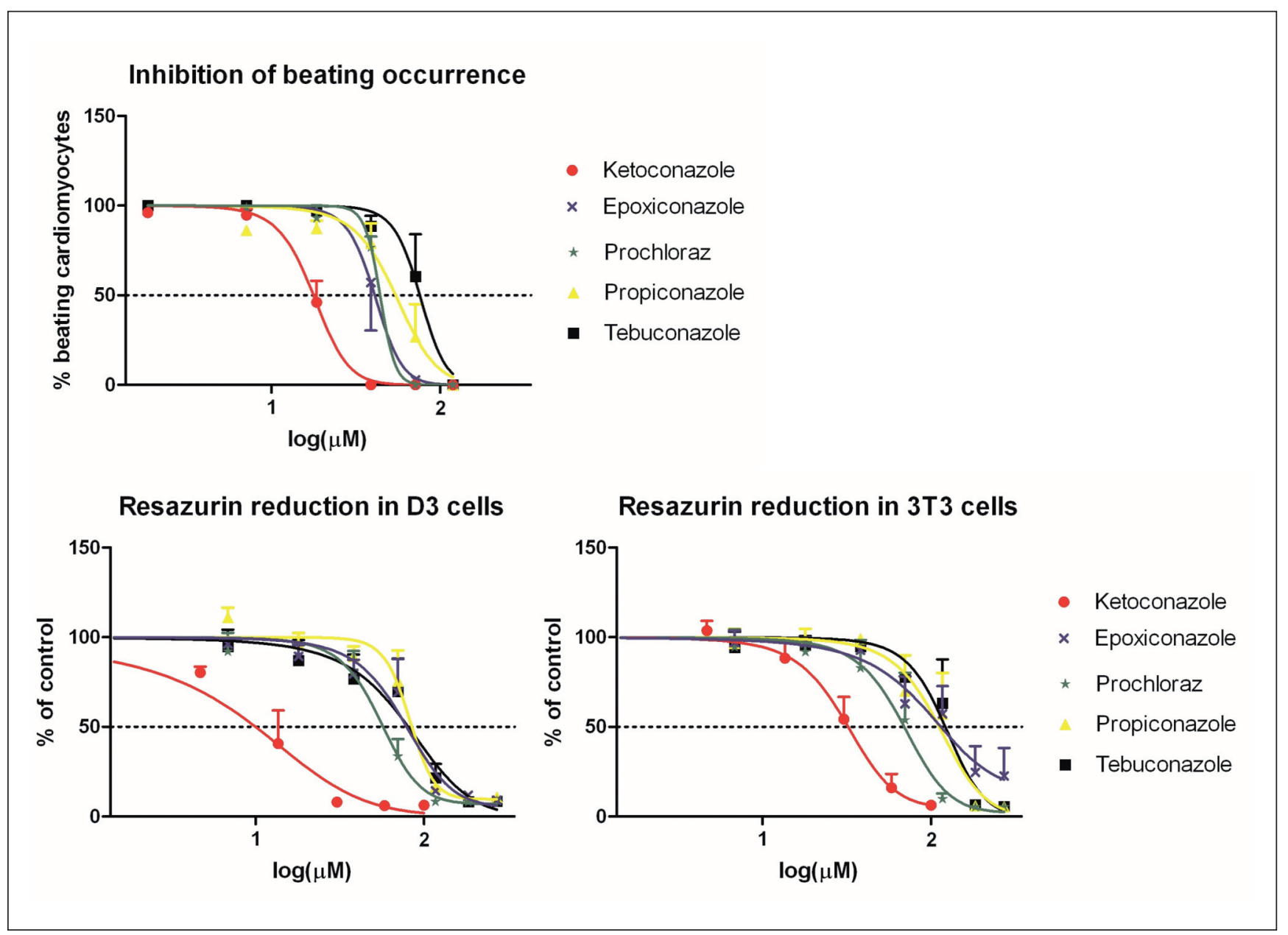

Fig. 1: Dose-response curves for inhibition of beating occurrence of embryonic stem cells and resazurin reduction in D3 and 3T3 cells for five selected conazole fungicides

Beating occurrence was evaluated in three independent experiments (except for tebuconazole, which was tested four times) and the resazurin reduction experiments were conducted four times (except for ketoconazole, which was tested three times). Data represent mean \pm SEM. The horizontal dashed lines represent $50 \%$ of control level.

Tab. 1: Embryonic Stem Cell Test endpoints for five conazole compounds

EST endpoints and their 95\% confidence intervals (95\% C.I.) were derived from the non-linear regressions to the plots in Fig. 1; $\mathrm{a}=\mathrm{ID}_{50}$ and/or $I \mathrm{IC}_{50}$ values were considered different as their $95 \%$ C.I. were not overlapping.

\begin{tabular}{|c|c|c|c|c|c|c|}
\hline \multirow[b]{2}{*}{$\begin{array}{l}\text { Conazole } \\
\text { fungicide }\end{array}$} & \multicolumn{6}{|c|}{ In vitro EST assay endpoints } \\
\hline & $\begin{array}{l}I_{50}, \mu \mathrm{M} \\
(95 \% \text { C.I. })\end{array}$ & $\begin{array}{c}\mathrm{IC}_{50} \mathrm{D} 3, \mu \mathrm{M} \\
(95 \% \text { C.I. })\end{array}$ & $\begin{array}{c}\mathrm{IC}_{503 \mathrm{~T}}, \mu \mathrm{M} \\
(95 \% \text { C.I. })\end{array}$ & $\begin{array}{c}\text { EST } \\
\text { classification }\end{array}$ & $\begin{array}{c}\mathrm{ID}_{50} / \mathrm{IC}_{50} \mathrm{D} 3 \\
\text { ratio }\end{array}$ & $\begin{array}{c}\mathrm{IC}_{50} \mathrm{D} 3 / \mathrm{IC} \mathrm{C}_{50} 3 \mathrm{TT} 3 \\
\text { ratio }\end{array}$ \\
\hline Epoxiconazole & $33.8(25.6-44.5)$ & $69.4(51.3-94.0)$ & $97.0(40.1-234.6)$ & Weakly embryotoxic & $0.5^{\mathrm{a}}$ & 0.7 \\
\hline Ketoconazole & $15.4(14.1-16.9)$ & $9.9(7.0-14.1)$ & $25.6(20.3-32.2)$ & Weakly embryotoxic & 1.6 & $0.4^{\mathrm{a}}$ \\
\hline Prochloraz & $36.5(24.6-54.2)$ & $46.7(38.7-56.5)$ & $60.1(42.4-87.2)$ & Weakly embryotoxic & 0.8 & 0.8 \\
\hline Propiconazole & $46.3(31.8-67.3)$ & $76.1(62.0-93.4)$ & $116.8(69.7-195.5)$ & Weakly embryotoxic & 0.6 & 0.7 \\
\hline Tebuconazole & $69.1(44.4-107.4)$ & $74.7(44.0-126.6)$ & $131.9(87.1-199.9)$ & Weakly embryotoxic & 0.9 & 0.6 \\
\hline
\end{tabular}


to identify embryotoxic compounds (van Dartel et al., 2011; West et al., 2010). Chandler et al. (2011) modified to deliver a high-throughput, sensitive method for quantitatively measuring cardiomyocyte differentiation using primary mouse antibody that recognizes $\alpha$ and $\beta$ cardiac myosin heavy chain. Two of the present fungicides, i.e., prochloraz and propiconazole, were tested along with other related conazole compounds. Half-maximal activity concentration ( $\mathrm{AC}_{50}$ ) values for cardiomyocyte differentiation were determined to be 12 and 9, respectively. These values are lower than the ID50 values found in this study and indicate that expanding the endpoints in the EST might heighten the sensitivity of this assay.

The $\mathrm{ID}_{50} / \mathrm{IC}_{50} \mathrm{D} 3$ ratio was used as a measure for specific inhibition of the differentiation process versus cytotoxicity (Stummann et al., 2008). The 95\% confidence intervals for the ID 50 and $\mathrm{IC}_{50} \mathrm{D} 3$ were not substantially different for prochloraz, ketoconazole, tebuconazole, and propiconazole implying no specific interference with cardiac differentiation, i.e., their ID $50 / \mathrm{IC}_{50} \mathrm{D} 3$ ratios are not significantly different from 1 . In contrast, epoxiconazole had non-overlapping 95\% C.I. and an ID $50 /$ $\mathrm{IC}_{50} \mathrm{D} 3$ ratio of 0.5 (Tab. 1) indicating that this conazole fungicide may induce specific inhibition of cardiac differentiation.
Similarly, $\mathrm{IC}_{50} \mathrm{D} 3 / \mathrm{IC}_{50} 3 \mathrm{~T} 3$ ratios were estimated to compare the D3 cell toxicity versus 3T3 fibroblast cytotoxicity. Ketoconazole exhibited an $\mathrm{IC}_{50} \mathrm{D} 3 / \mathrm{IC}_{50} 3 \mathrm{~T} 3$ ratio below 0.5 with nonoverlapping $95 \%$ confidence intervals between the $\mathrm{IC}_{50} \mathrm{D} 3$ and $\mathrm{IC}_{50} 3 \mathrm{~T} 3$ values indicating a greater sensitivity of embryonic cells towards the cytotoxic effects of this fungicide. Ketoconazole inhibited the embryonic differentiation process at significantly lower concentrations than the other conazoles, since ketoconazole had the lowest ID 50 value with non-overlapping $95 \%$ confidence intervals.

Although all five conazole compounds were classified as "weakly embryotoxic" by the PM, a ranking of the potencies according to the ID50 values was performed to position the compounds relative to their embryotoxicity, resulting in the following order: ketoconazole $>$ epoxiconazole $\approx$ prochloraz $>$ propiconazole $\approx$ tebuconazole.

Publically available data from in-house experiments or others' studies on selected in vivo embryotoxic effects of the conazoles were gathered and presented in Table 2. The endpoints included were direct toxic effects to the fetus such as implantation loss, fetal/birth weight, number of resorptions, number of live fetuses, malformations, postnatal death, and pup weight or

\section{Tab. 2: Overview of embryotoxicity in vivo data for five conazole compounds}

Ranges of doses in $\mathrm{mg} / \mathrm{kg}$ bw/day for significant effects on each specific endpoint are shown. Numbers in parentheses are the reference identification numbers as listed in Supplementary materials at www.altex-edition.org. Italic numbers refer to the tested dose range in $\mathrm{mg} / \mathrm{kg}$ bw/day in all included studies. $\mathrm{NI}=$ parameter not investigated, $\mathrm{NS}=$ effect not significant. The lowest lowest-observed-adverse-effect-level (LOAEL) value (in $\mathrm{mg} / \mathrm{kg}$ bw/day) for each chemical and parameter was converted into colors using an arbitrary scale selected as shown in the row marked scale. Non-significant effects were assigned the highest LOAEL value on the scale.

\begin{tabular}{|c|c|c|c|c|c|c|c|c|c|}
\hline \multirow[b]{2}{*}{$\begin{array}{l}\text { Conazole } \\
\text { fungicides } \\
\text { (mg/kg bw/day) }\end{array}$} & \multicolumn{9}{|c|}{ In vivo embryotoxicity endpoints } \\
\hline & $\begin{array}{l}\text { Gestation } \\
\text { length }\end{array}$ & $\begin{array}{c}\text { Maternal } \\
\text { weight gain }\end{array}$ & $\begin{array}{c}\text { Implantat- } \\
\text { ion loss }\end{array}$ & $\begin{array}{c}\text { Fetal/birth } \\
\text { weight }\end{array}$ & $\begin{array}{l}\text { Resorpt- } \\
\text { ions }\end{array}$ & $\begin{array}{c}\text { Live } \\
\text { fetuses }\end{array}$ & $\begin{array}{l}\text { Malformat } \\
\text {-ions }\end{array}$ & $\begin{array}{l}\text { Postnatal } \\
\text { death }\end{array}$ & $\begin{array}{c}\text { Pup } \\
\text { weight }\end{array}$ \\
\hline $\begin{array}{l}\text { Epoxiconazole } \\
3.75-250\end{array}$ & $\begin{array}{c}\uparrow 15-50 \\
(1-3)\end{array}$ & $\begin{array}{c}\downarrow 20-180 \\
(4-6)\end{array}$ & $\begin{array}{l}\uparrow 50-180 \\
(2,5,6,7)\end{array}$ & $\begin{array}{c}\downarrow \uparrow 15,50 \\
(2,7)\end{array}$ & $\begin{array}{c}\uparrow 45-180 \\
(4-7)\end{array}$ & $\begin{array}{c}\downarrow \approx 23-180 \\
(2,3,5)\end{array}$ & $\begin{array}{l}\uparrow 45 \\
(4)\end{array}$ & $\begin{array}{c}\uparrow \approx 23,50 \\
(2,3)\end{array}$ & $\begin{array}{l}\downarrow \hat{\partial} \approx 23 \\
(3)\end{array}$ \\
\hline $\begin{array}{l}\text { Ketoconazole } \\
50-100\end{array}$ & $\mathrm{NI}$ & $\begin{array}{c}\downarrow 50,100 \\
(7,8)\end{array}$ & $\begin{array}{c}\uparrow 10-100 \\
(7-10)\end{array}$ & $\begin{array}{c}\downarrow 80,100 \\
(8,9)\end{array}$ & $\begin{array}{c}\uparrow 50-100 \\
(7-10)\end{array}$ & $\begin{array}{c}\downarrow 40-80 \\
(7,11)\end{array}$ & $\begin{array}{c}\uparrow 80 \\
(9,11)\end{array}$ & $\mathrm{NI}$ & $\mathrm{NI}$ \\
\hline $\begin{array}{l}\text { Prochloraz } \\
5-500\end{array}$ & $\begin{array}{c}\uparrow 30-250 \\
(12-15)\end{array}$ & $\begin{array}{c}\downarrow 30-500 \\
(12,13,15-18)\end{array}$ & $\begin{array}{c}\uparrow 250 \\
(13)\end{array}$ & $\begin{array}{l}\uparrow \uparrow 62.5 \\
\downarrow\langle 100 \\
(13,18)\end{array}$ & $\begin{array}{l}\uparrow 160 \\
(19)\end{array}$ & $\begin{array}{c}\uparrow 58-81 \\
(15)\end{array}$ & $\begin{array}{c}\uparrow 50-250 \\
(13,17)\end{array}$ & $\begin{array}{c}\uparrow 58-250 \\
(13,15)\end{array}$ & $\begin{array}{c}\downarrow 125-250 \\
(13,14)\end{array}$ \\
\hline $\begin{array}{l}\text { Propiconazole } \\
\approx 7.6-414\end{array}$ & $\mathrm{NI}$ & $\begin{array}{l}\text { NS } \\
(7)\end{array}$ & $\begin{array}{l}\text { NS } \\
(7)\end{array}$ & $\begin{array}{c}\uparrow \circlearrowleft 50 \\
(7)\end{array}$ & $\begin{array}{l}\text { NS } \\
(7)\end{array}$ & $\begin{array}{l}\downarrow 250 \\
(20)\end{array}$ & $\begin{array}{c}\uparrow 90,400 \\
(21,22)\end{array}$ & $\mathrm{NI}$ & $\begin{array}{c}\downarrow \overrightarrow{0} \approx 145-414 \\
(20,23)\end{array}$ \\
\hline $\begin{array}{l}\text { Tebuconazole } \\
6-988\end{array}$ & $\begin{array}{l}\uparrow 100 \\
\text { (2) }\end{array}$ & $\begin{array}{l}\downarrow 60,100 \\
(2,24)\end{array}$ & $\begin{array}{c}\uparrow 50,100 \\
(2,7)\end{array}$ & $\begin{array}{l}\downarrow 60,100 \\
(2,24,25)\end{array}$ & $\begin{array}{l}\text { NS } \\
(2,7)\end{array}$ & $\begin{array}{l}\downarrow 100 \\
(26)\end{array}$ & $\begin{array}{c}\uparrow 30-120 \\
(25-28)\end{array}$ & $\begin{array}{l}\uparrow 60,100 \\
(2,24,29)\end{array}$ & $\begin{array}{l}\downarrow 100 \\
(29)\end{array}$ \\
\hline
\end{tabular}

\section{Scale}

\begin{tabular}{|l|l|l}
\hline LOAEL $\leq 10$ & $10<$ LOAEL $\leq 30$ & $30<$ LOAEL $\leq 50$
\end{tabular}

$50<$ LOAEL $\leq 70$

$70<\mathrm{LOAEL} \leq 100$

LOAEL $>100$ 
maternal effects such as gestational length and maternal weight gain. Although maternal weight gain and gestational length may be due to other mechanisms, such as maternal toxicity or hormonal changes, respectively, they were included as embryotoxic parameters, since they both can lead to increased fetal death. In this study, ranking the conazole fungicides relative to in vivo embryotoxicity was based on the lowest lowest-observed-adverse-effect-levels (LOAELs) and the number of affected endpoints among the selected endpoints in the table, resulting in the following order: ketoconazole $>$ epoxiconazole $>$ prochloraz $>$ propiconazole $\approx$ tebuconazole. This order is fairly similar for in vivo and in vitro data, and we therefore conclude that the qualitative embryotoxic potential is fairly well predicted by the EST for these five conazoles. However, in vivo potency of epoxiconazole compared to prochloraz could not be discriminated by the EST.

Various in vivo data indicate that the timing of exposure during gestation may be important for the adverse effects observed. Taxvig et al. $(2007,2008)$ found that epoxiconazole had several adverse embryotoxic outcomes such as increased post-implantation loss and late resorptions in Wistar rats (Tab. 2). De Castro and Maia (2012) investigated the effects of epoxiconazole in the same rat strain and did not find developmental toxicity parameters to be altered even at a dose of $150 \mathrm{mg} / \mathrm{kg}$ bw/day. Differences in the dosing period between the studies (i.e., GD16 or GD6-15 in the de Castro study versus from GD7-21 and throughout lactation in the Taxvig study) are likely to explain the observed difference. This would imply that dosing during the final week of pregnancy or during lactation may be the critical period of concern of exposure to epoxiconazole (de Castro and Maia, 2012). Choosing the relevant dosing period is critical regarding developmental toxicity, not only for conazoles, but for all chemicals.

Other in vitro models have studied the embryotoxic effects of the conazole compounds. Among these are the post-implantation whole embryo culture (WEC) teratogenicity assay that investigates the growth in vitro of rodent embryos during some days in the period of organogenesis (Giavini and Menegola, 2010). Several WEC studies using rat or mouse embryos showed that conazoles were able to produce specific malformations in embryos. For instance, tebuconazole induced branchial arches malformations at exposure levels of 62.5-250 $\mu \mathrm{M}$ and in a concentration-related manner in the rat WEC system (Di Renzo et al., 2011). Additionally, severe abnormalities including abnormally shaped otic vesicle and head length were concentration-related and observed in rat embryos exposed to 10-100 $\mu \mathrm{M}$ ketoconazole (Menegola et al., 2006; Bechter and Schmid, 1987; Kucera et al., 1993). Also, propiconazole interfered with embryonic development of the crustacean Daphnia magna (Kast-Hutcheson et al., 2001). In a study by de Jong et al. (2011) comparing EST, rat WEC, and the Zebrafish Embryotoxicity Test (ZET), six related triazole compounds inhibited cardiomyocyte differentiation concentration-dependently in EST. These data support the hypothesis regarding the suggested embryotoxicity potential of the conazoles and further underline that this may be a general effect caused by this class of chemicals. The study also concluded that ZET gave the best correlation with the relative in vivo toxicities of the test compounds, closely followed by the EST.

The same group also developed a novel quantitative evaluation method to assess the development of the zebrafish embryo based on specific endpoints in time, i.e., the general morphology score (GMS) system, and found comparable ranking of the six tested triazole compounds with ranking in vivo (Hermsen et al., 2011). As pinpointed by this group, it is unlikely that one single alternative testing method will be able to give a prediction for the entire range of possible mechanisms. Beside their embryotoxic effects, triazoles and imidazoles share endocrine disrupting modes of actions with imidazoles being found to be more potent than triazoles (Kjaerstad et al., 2010b). Results from various in vitro studies on endocrine disrupting effects of the conazoles are gathered and presented in Table 3 . These include receptor reporter gene assays testing for antagonism or increase in transactivational activity of the androgen (AR), estrogen (ER), and aryl hydrocarbon (AhR) receptors along with studies investigating interference with sex hormone synthesis.

The critical mechanism for both imidazoles and triazoles seems to be inhibition of sex hormone biosynthesis, as these effects occur at lower concentrations compared to effect concentrations obtained in the nuclear receptor-based assays (Tab. 3 ). Ranking of in vitro endocrine activity of the conazole compounds was therefore carried out solely based on data from the steroidogenesis assay based on H295R cells. The ranking of the five compounds in terms of in vitro potency on interference with steroidogenesis (Tab. 3) was found to be:

Decreased estradiol production:

prochloraz $>$ epoxiconazole $>$ ketoconazole $\approx$ propiconazole $\approx$ tebuconazole

Decreased testosterone production:

prochloraz $>$ ketoconazole $>$ tebuconazole $>$ epoxiconazole $>$ propiconazole

Increased progesterone production:

prochloraz $>$ epoxiconazole $=$ propiconazole $>$ ketoconazole $>$ tebuconazole

Aromatase inhibition:

prochloraz $>$ ketoconazole $\approx$ propiconazole $\approx$ epoxiconazole $>$ tebuconazole

The effect of the conazoles on key enzymes involved in the biosynthesis and metabolism of steroids is well known, i.e., inhibition of CYP19 (Vinggaard et al., 2000; Taxvig et al., 2007; Kjaerstad et al., 2010b) and CYP17 (Laier et al., 2006). In vivo, the conazole fungicides also affect hormone levels in dams, i.e., ketoconazole, tebuconazole, prochloraz, and epoxiconazole reduced estradiol levels, and epoxiconazole increased testosterone plasma concentration in dams after exposure during pregnancy (Taxvig et al., 2007, 2008; Blystone et al., 2007). This may be the result of aromatase inhibition by these substances. Furthermore, epoxiconazole and tebuconazole increased progesterone levels in dams on GD21, i.e., one or two days before expected birth (Taxvig et al., 2007, 2008). Overall these data are in line with the hormonal effects observed in the H295R assay (Tab. 3 ). The effects on testosterone and progesterone biosynthesis 
Tab. 3: Overview of data for five conazole fungicides obtained from in vitro assays commonly used to evaluate endocrine disrupting properties

Range of lowest-observed-effect-concentrations (LOECs), EC 50 (effect concentration eliciting $50 \%$ of maximum response),

$\mathrm{IC}_{25 / 50}$ (inhibitory concentration resulting in $25 \%$ or $50 \%$ of control response, respectively), or $\mathrm{REC}_{20}$ (relative effective concentration eliciting $20 \%$ of positive agonist response) values in $\mu \mathrm{M}$ are shown. Numbers in parentheses are the reference identification numbers as listed in Supplementary materials at www.altex-edition.org. AhR = aryl hydrocarbon receptor, $A R=$ androgen receptor, $\mathrm{NI}=$ parameter not investigated. Colors indicate the potency of each chemical in each assay. Potency in terms of exposure concentrations were converted into colors using an arbitrary scale selected as shown in the row marked scale.

\begin{tabular}{|c|c|c|c|c|c|c|c|}
\hline \multirow{3}{*}{$\begin{array}{l}\text { Conazole } \\
\text { fungicide }\end{array}$} & \multicolumn{7}{|c|}{ In vitro endpoints for endocrine disruption } \\
\hline & \multirow{2}{*}{$\begin{array}{c}\text { AR } \\
\text { antagonism }\end{array}$} & \multirow{2}{*}{$\begin{array}{l}\text { Antiestroge- } \\
\text { nicity }\end{array}$} & \multirow{2}{*}{$\begin{array}{l}\text { AhR trans- } \\
\text { activation }\end{array}$} & \multicolumn{4}{|c|}{ Steroidogenesis } \\
\hline & & & & $\begin{array}{c}\text { Estradiol } \\
\text { production } \downarrow\end{array}$ & $\begin{array}{l}\text { Testosterone } \\
\text { production } \downarrow\end{array}$ & $\begin{array}{l}\text { Progesterone } \\
\text { production } \uparrow\end{array}$ & $\begin{array}{l}\text { Aromatase } \\
\text { inhibition }\end{array}$ \\
\hline \multirow[t]{3}{*}{ Epoxiconazole } & $\begin{array}{c}\text { LOEC:1.6-2 } \\
(1,30,31)\end{array}$ & $\begin{array}{l}\text { LOEC:25 } \\
(30)\end{array}$ & $\begin{array}{l}\text { LOEC:6.3 } \\
\text { (33) }\end{array}$ & $\begin{array}{l}\text { LOEC:0.1 } \\
\text { (30) }\end{array}$ & $\begin{array}{l}\text { LOEC:3 } \\
(30)\end{array}$ & $\begin{array}{l}\text { LOEC:0.3 } \\
\text { (30) }\end{array}$ & $\begin{array}{l}\text { LOEC: } 1-100 \\
(30,34,35)\end{array}$ \\
\hline & $\begin{array}{c}3<1 \mathrm{C}_{25}<10 \\
(32)\end{array}$ & $\begin{array}{c}\mathrm{IC}_{50}: 52 \\
(30)\end{array}$ & & $\begin{array}{l}I C_{50}: 0.2 \\
(30)\end{array}$ & $\begin{array}{l}I_{50}: 5.3 \\
(30)\end{array}$ & & $\begin{array}{c}I_{50}: 1.44-20 \\
(30,34,36)\end{array}$ \\
\hline & $\begin{array}{l}I_{50: 10} \\
(30)\end{array}$ & & & & & & \\
\hline \multirow[t]{2}{*}{ Ketoconazole } & $\begin{array}{c}3<1 C_{25}<10 \\
\quad(32)\end{array}$ & $\begin{array}{l}\text { LOEC:0.2 } \\
\text { (30) }\end{array}$ & $\mathrm{NI}$ & $\begin{array}{l}\text { LOEC: } 1-5 \\
(30,37-40)\end{array}$ & $\begin{array}{l}\text { LOEC:0.03-9.4 } \\
(30,37-40,42-44)\end{array}$ & $\begin{array}{l}\text { LOEC: } 1-5 \\
(30,37,40)\end{array}$ & $\begin{array}{c}\text { LOEC:6.3 } \\
(30)\end{array}$ \\
\hline & & $\begin{array}{c}I_{50: 12} \\
(30)\end{array}$ & & $\begin{array}{c}\mathrm{IC}_{50}: 0.62-2.3 \\
(30,41)\end{array}$ & $\begin{array}{c}I_{50}: 0.08-0.26 \\
(30,41,45)\end{array}$ & & $\begin{array}{l}{ }^{I} C_{50}: 0.9-281 \\
(30,34,46-51)\end{array}$ \\
\hline \multirow[t]{3}{*}{ Prochloraz } & $\begin{array}{c}\text { LOEC:1.9-10 } \\
(1,13,30,52)\end{array}$ & $\begin{array}{l}\text { LOEC:1-25 } \\
(30,52,56)\end{array}$ & $\begin{array}{l}\text { LOEC:0.05-1 } \\
\quad(33,57)\end{array}$ & $\begin{array}{c}\text { LOEC:0.01-5 } \\
(17,30,37-40)\end{array}$ & $\begin{array}{l}\text { LOEC:0.01-30 } \\
(17,30,37-40,59)\end{array}$ & $\begin{array}{c}\text { LOEC:0.01-5 } \\
(17,30,37,40)\end{array}$ & $\begin{array}{c}\text { LOEC:0.3-50 } \\
(30,34,38,52,61,62)\end{array}$ \\
\hline & $\begin{array}{c}3<1 \mathrm{C}_{25}<10 \\
(32)\end{array}$ & $\begin{array}{c}\mathrm{IC}_{50: 22-29} \\
(30,56)\end{array}$ & $\begin{array}{c}\operatorname{REC}_{20}: 0.71 \\
(58)\end{array}$ & $\begin{array}{c}I_{50} C_{50} 0.02 \\
(30)\end{array}$ & $\begin{array}{c}I_{50}: 0.005 \\
(30)\end{array}$ & $\begin{array}{c}\mathrm{EC}_{50}: 0.21 \\
(41)\end{array}$ & $\begin{array}{c}I_{50}: 0.047-15 \\
(30,34,50,51,60-62)\end{array}$ \\
\hline & $\begin{array}{c}I_{50}: 3.6-13 \\
(30,53-55)\end{array}$ & & & & & & \\
\hline \multirow[t]{3}{*}{ Propiconazole } & $\begin{array}{c}\text { LOEC:12.5-25 } \\
(30,31)\end{array}$ & $\begin{array}{l}\text { LOEC:1 } \\
(30)\end{array}$ & $\begin{array}{l}\text { LOEC: } 12.5 \\
\text { (33) }\end{array}$ & $\begin{array}{l}\text { LOEC:1-30 } \\
\quad(30,63)\end{array}$ & $\begin{array}{l}\text { LOEC:10 } \\
(30,63)\end{array}$ & $\begin{array}{l}\text { LOEC:0.3 } \\
\quad(30)\end{array}$ & $\begin{array}{c}\text { LOEC:1-50 } \\
(30,61,62)\end{array}$ \\
\hline & $\begin{array}{c}3<1 C_{25}<10 \\
(32)\end{array}$ & $\begin{array}{l}\mathrm{IC}_{50}: 55 \\
(30)\end{array}$ & & $\begin{array}{c}I_{50}: 0.9 \\
(30)\end{array}$ & $\begin{array}{l}I C_{50: 5.3} \\
(30)\end{array}$ & & $\begin{array}{c}I_{50}: 0.968-199 \\
(30,34,51,60-62,64)\end{array}$ \\
\hline & $\begin{array}{c}\mathrm{IC}_{50}: 18 \\
(30)\end{array}$ & & & & & & \\
\hline \multirow[t]{2}{*}{ Tebuconazole } & $\begin{array}{c}\text { LOEC:0.5-3.8 } \\
(1,30,31) \\
1<1 C_{25}<3 \\
(32)\end{array}$ & $\begin{array}{l}\text { LOEC: } 1.6 \\
(30) \\
I_{50}: 49 \\
(30)\end{array}$ & $\begin{array}{c}\text { LOEC:6.3 } \\
\text { (33) }\end{array}$ & $\begin{array}{c}\text { LOEC:3 } \\
(30) \\
I_{50}: 1.2 \\
(30)\end{array}$ & $\begin{array}{l}\text { LOEC:0.1 } \\
\qquad \begin{array}{l}(30) \\
I_{50}: 0.5 \\
(30)\end{array}\end{array}$ & $\begin{array}{l}\text { LOEC:10 } \\
(30)\end{array}$ & $\begin{array}{c}\text { LOEC: } 10 \\
(30) \\
I_{50}: 5.8-609 \\
(30,34,51,60)\end{array}$ \\
\hline & $\begin{array}{c}I_{50}: 8.1 \\
(30)\end{array}$ & & & & & & \\
\hline Scale & $x \leq 0.05$ & $0.05<x \leq 0.1$ & $0.1<x \leq 0.5$ & $0.5<x \leq$ & $1<x$ & & $x>5$ \\
\hline
\end{tabular}

indicate an inhibition of enzymes involved in the conversion of progesterone to testosterone and might be due, at least partly, to inhibition of CYP17 (Laier et al., 2006), an effect that has been confirmed in vitro in $\mathrm{H} 295 \mathrm{R}$ cells and in testicular microsomes (Blystone et al., 2007; Ayub and Levell, 1987; Ohlsson et al., 2010). The increased progesterone levels in the dams are suggested to cause virilization of the female offspring (Taxvig et al., 2007), which would explain the increased AGD in females pups observed after exposure to several of the conazoles (Tab. 4). In addition, the increased progesterone levels in dams could explain the prolonged pregnancy period (Tab. 2) (Vinggaard et al., 2005).

Data on endpoints from in vivo developmental toxicity endpoints affected by the conazole fungicides were collected and presented in Table 4. The parameters included common endpoints such as male reproductive organ weight, anogenital 
Tab. 4: Overview of data for five conazole compounds causing significant in vivo developmental toxicity

Ranges of doses in $\mathrm{mg} / \mathrm{kg}$ bw/day are shown; $\uparrow \downarrow$ indicate an increase or decrease in the investigated parameter, respectively. Numbers in parentheses are the reference identification numbers as listed in Supplementary materials at www.altex-edition.org. Italic numbers refer to the tested dose range in $\mathrm{mg} / \mathrm{kg}$ bw/day in all included studies. AGD $=$ anogenital distance, $\mathrm{NI}=$ parameter not investigated, NS = effect not significant. Lowest-observed-adverse-effect-level (LOAEL) values (in mg/kg bw/day) were converted into colors using an arbitrary scale selected as shown in the row marked scale. Non-significant effects were assigned the highest LOAEL value in the scale. Diagonal hatching was assigned to results that indicate an increase in feminization of female offspring or a masculinization of male offspring, respectively.

\begin{tabular}{|c|c|c|c|c|c|c|c|c|c|}
\hline \multirow[b]{3}{*}{$\begin{array}{l}\text { Conazole } \\
\text { fungicide } \\
\text { (mg/kg bw/day) }\end{array}$} & \multicolumn{9}{|c|}{ In vivo developmental toxicity endpoints } \\
\hline & \multirow[b]{2}{*}{$\begin{array}{l}\text { Repro- } \\
\text { ductive } \\
\text { organ } \\
\text { weight } \hat{\sigma}\end{array}$} & \multicolumn{2}{|c|}{ AGD } & \multirow[b]{2}{*}{$\begin{array}{l}\text { No. } \\
\text { areolas } \widehat{\diamond}\end{array}$} & \multicolumn{4}{|c|}{ Hormone levels in $\widehat{o}$ pups } & \multirow[b]{2}{*}{ Other } \\
\hline & & $\hat{0}$ & 우 & & $\begin{array}{l}\text { Testos- } \\
\text { terone }\end{array}$ & \begin{tabular}{|l} 
Proges- \\
terone
\end{tabular} & $\begin{array}{l}\text { 17a- } \\
\text { hydroxy- } \\
\text { proges- } \\
\text { terone }\end{array}$ & $\begin{array}{l}\text { Andro- } \\
\text { stene- } \\
\text { dione }\end{array}$ & \\
\hline $\begin{array}{l}\text { Epoxiconazole } \\
\approx 1-15\end{array}$ & $\begin{array}{l}\uparrow 15 \\
(65)\end{array}$ & $\begin{array}{l}\uparrow 3.75,15 \\
(1,2)\end{array}$ & $\begin{array}{l}\uparrow 3.75-50 \\
(1,2)\end{array}$ & $\begin{array}{l}\text { NS } \\
\text { (2) }\end{array}$ & $\begin{array}{l}\text { NS } \\
(7)\end{array}$ & $\begin{array}{l}\text { NS } \\
(7)\end{array}$ & $\begin{array}{l}\text { NS } \\
(2)\end{array}$ & $\mathrm{NI}$ & $\begin{array}{l}\text { Time to vaginal } \\
\text { opening } \downarrow 150 \\
\text { Time to testes } \\
\text { descent } \uparrow 150 \\
\text { (66) }\end{array}$ \\
\hline $\begin{array}{l}\text { Ketoconazole } \\
50\end{array}$ & $\mathrm{NI}$ & $\begin{array}{l}\downarrow 50 \\
(7)\end{array}$ & $\begin{array}{l}\downarrow 50 \\
(7)\end{array}$ & $\mathrm{NI}$ & $\begin{array}{l}\downarrow 50 \\
(7)\end{array}$ & $\mathrm{NI}$ & $\mathrm{NI}$ & $\mathrm{NI}$ & - \\
\hline $\begin{array}{l}\text { Prochloraz } \\
5-500\end{array}$ & $\begin{array}{l}\downarrow 30-250 \\
(12,13,16, \\
17,65)\end{array}$ & $\begin{array}{l}\downarrow 50-150 \\
(13,17)\end{array}$ & $\begin{array}{l}\uparrow 8.75-150 \\
(1,13,17)\end{array}$ & $\begin{array}{l}\uparrow 30-250 \\
(1,12,13,17)\end{array}$ & $\begin{array}{l}\downarrow 30-250 \\
(12,16,17,67)\end{array}$ & $\begin{array}{l}\downarrow 50 \\
\uparrow 7.8-250 \\
(12,16,17,67)\end{array}$ & $\begin{array}{l}\uparrow 7.8-125 \\
(16)\end{array}$ & $\begin{array}{l}\downarrow 31.3,125 \\
(16)\end{array}$ & - \\
\hline $\begin{array}{l}\text { Propiconazole } \\
\approx 7.6-414\end{array}$ & $\begin{array}{l}\uparrow \approx 36-414 \\
(23)\end{array}$ & $\begin{array}{l}\uparrow \approx 145-174 \\
(23)\end{array}$ & $\begin{array}{l}\text { NS } \\
(23)\end{array}$ & $\mathrm{NI}$ & $\begin{array}{l}\uparrow \approx 36-414 \\
(23)\end{array}$ & $\mathrm{NI}$ & $\mathrm{NI}$ & $\mathrm{NI}$ & $\begin{array}{l}\text { Female fertility } \\
\downarrow \approx 36-414 \\
(22,23)\end{array}$ \\
\hline $\begin{array}{l}\text { Tebuconazole } \\
12.5-988\end{array}$ & $\begin{array}{l}\downarrow 60-988 \\
(24,29,68)\end{array}$ & $\begin{array}{l}\uparrow 100 \\
(2)\end{array}$ & $\begin{array}{l}\uparrow 12.5-100 \\
(1,2)\end{array}$ & $\begin{array}{l}\uparrow 50,100 \\
(1,2)\end{array}$ & $\begin{array}{l}\downarrow 100 \\
(2)\end{array}$ & $\begin{array}{l}\uparrow 50 \\
(2,7)\end{array}$ & $\begin{array}{l}\uparrow 50,100 \\
(2)\end{array}$ & $\mathrm{NI}$ & $\begin{array}{l}\text { Fertility } \\
\downarrow 300 \\
(29)\end{array}$ \\
\hline
\end{tabular}

\begin{tabular}{|l|l|l|l|l|l|l|}
\hline Scale & LOAEL $\leq 10$ & $10<$ LOAEL $\leq 30$ & $30<$ LOAEL $\leq 50$ & $50<$ LOAEL $\leq 70$ & $70<$ LOAEL $\leq 100$ & LOAEL $>100$ \\
\hline
\end{tabular}

distance (AGD), number of male areolas, and hormone levels in pups. There is, however, a lack of available data on ketoconazole in that respect. The in vivo findings suggest that prochloraz, ketoconazole, and tebuconazole mainly affect male reproductive health endpoints - effects that conceivably are mediated by reduced testosterone during gestation. The findings on epoxiconazole and propiconazole indicate that they mainly affect female reproductive health, e.g., disruption of estrous cycle (Rockett et al., 2006) and time until vaginal opening (de Castro and Maia, 2012) defining the onset of puberty in female rats (Firlit and Schwartz, 1977). These two conazoles also show a weak estrogenic response in vitro in the MCF-7 cell proliferation assay (data not included in Tab. 3) (Kjaerstad et al., 2007), a mode of action that might contribute to the effect on female reproduction. Prochloraz, keto- conazole, and tebuconazole seem to be the most potent male reproductive toxicants affecting either male AGD, nipple retention and/or fetal testosterone. On the other hand, epoxiconazole and propiconazole seem to affect the female pups to a higher degree. Overall, prochloraz ranks the most potent endocrine disruptor based on interference with steroidogenesis in vitro (Tab. 3 ). In agreement with this, in vivo data show that prochloraz appears to affect all studied endpoints adversely and propiconazole shows the lowest potency both in vitro and in vivo. Affinities and potencies for selected CYP enzymes, i.e., CYP17, CYP19, CYP26, and CYP51, appear to be the mechanism eliciting the functional and adverse effects of the conazole fungicides and differential CYP inhibition profiles may explain the observed differences in their embryotoxic and developmental toxic profile. 


\section{Conclusion}

The overall objective of this study was to retrospectively evaluate the predictability of a battery of in vitro methods for evaluating embryotoxicity and developmental toxicity for five conazole fungicides. All five conazoles were classified as "weakly embryotoxic" in the EST, and ranking of their potencies based on $\mathrm{ID}_{50}$ values for inhibition of beating occurrence in cardiomyocytes showed fairly good correlation with in vivo embryotoxic endpoints. However, in animal studies epoxiconazole appeared to have a stronger embryotoxic potential compared to prochloraz, a difference that was not predicted by EST. The critical mechanism for both imidazoles and triazoles on endpoints of developmental toxicity seems to be inhibition of enzymes involved in sex hormone biosynthesis. Based on data from the H295R steroidogenesis assay prochloraz was found to be the most potent endocrine disruptor in vitro, an effect that resulted in a broader variety of adverse in vivo developmental effects.

The disparity in influence on adverse in vivo developmental and embryotoxic effects observed between the conazole fungicides is likely a result of differences in affinities and potencies for the various CYP enzymes (i.e., CYP17, CYP19, and CYP26) believed to be affected during gestation and/or lactation. In this paper we showed that a battery of in vitro test methods, including the H295R steroidogenesis assay and the EST assay can be used as an effective initial approach for ranking of conazoles in relation to adverse health effects such as developmental toxicity and embryotoxicity. Data obtained from the AR, ER, and AhR reporter gene assays and the CYP19 assays contributed with mechanistic information but were not determining factors for the in vivo predictability for this class of compounds. Thus, a holistic evaluation of a battery of relevant assays may give important hints on the toxicological outcome in animal studies and hints on the critical mode and mechanisms of action of the chemicals, thereby saving resources and animals in the design of potential future studies.

\section{References}

Adler, S., Pellizzer, C., Hareng, L., et al. (2008). First steps in establishing a developmental toxicity test method based on human embryonic stem cells. Toxicol In Vitro 22, 200-211.

Amaral, V. C. and Nunes, G. P. Jr. (2008). Ketoconazole- and fluconazole-induced embryotoxicity and skeletal anomalies in wistar rats: A comparative study. Brazilian Archives of Biology and Technology 51, 1153-1161.

Amaral, V. C. and Nunes, G. P. Jr. (2009). Prednisone reduces ketoconazole-induced skeletal defects in rat fetuses. Arch Toxicol 83, 863-871.

Andersen, H. R., Vinggaard, A. M., Rasmussen, T. H., et al. (2002). Effects of currently used pesticides in assays for estrogenicity, androgenicity, and aromatase activity in vitro. Toxicol Appl Pharmacol 179, 1-12.

Ayub, M. and Levell, M. J. (1987). Inhibition of rat testicular 17 alpha-hydroxylase and 17,20-lyase activities by anti-androgens (flutamide, hydroxyflutamide, RU23908, cyproterone acetate) in vitro. J Steroid Biochem 28, 43-47.
Ayub, M. and Levell, M. J. (1988). Structure-activity relationships of the inhibition of human placental aromatase by imidazole drugs including ketoconazole. J Steroid Biochem 31, 65-72.

Bechter, R. and Schmid, B. P. (1987). Teratogenicity in vitro - A comparative study of four antimycotic drugs using the wholeembryo culture system. Toxicol In Vitro 1, 11-15.

Becker (1988). CAPEG Database V1.2 and User Guide, External Scientific Report: Identification of cumulative assessment groups of pesticides. http://www.efsa.europa.eu/en/supporting/ pub/269e.htm (accessed 05.11.2012).

Becker, H., Mueller, E., Vogel, W., et al. (1988). Embryotoxicity study (including teratogenicity) with Prochloraz Technical in the rabbit (main study). Draft Assessment Report. Initial risk assessment report provided by rappoteur member state Ireland for the existing active substance PROCHLORAZ of the third stage (part B) of the review programme referred to in Article 8(2) of Council Directive 91/414/EEC.

Becker and Biedermann (1995). CAPEG Database V1.2 and User Guide, External Scientific Report: Identification of cumulative assessment groups of pesticides. http://www.efsa.europa.eu/en/ supporting/pub/269e.htm (accessed 05.11.2012).

Beswick, A. M. (1980). The teratogenicity study of technical Prochloraz in male and female rats. Draft Assessment Report. Initial risk assessment report provided by rappoteur member state Ireland for the existing active substance PROCHLORAZ of the third stage (part B) of the review programme referred to in Article 8(2) of Council Directive 91/414/EEC.

Birkhoj, M., Nellemann, C., Jarfelt, K., et al. (2004). The combined antiandrogenic effects of five commonly used pesticides. Toxicol Appl Pharmacol 201, 10-20.

Blake, L. S., Martinovic, D., Gray, L. E. Jr., et al. (2010). Characterization of the androgen-sensitive MDA-kb2 cell line for assessing complex environmental mixtures. Environ Toxicol Chem 29, 1367-1376.

Blystone, C. R., Lambright, C. S., Howdeshell, K. L., et al. (2007). Sensitivity of fetal rat testicular steroidogenesis to maternal prochloraz exposure and the underlying mechanism of inhibition. Toxicol Sci 97, 512-519.

Bonefeld-Jorgensen, E. C., Grunfeld, H. T., and Gjermandsen, I. M. (2005). Effect of pesticides on estrogen receptor transactivation in vitro: a comparison of stable transfected MVLN and transient transfected MCF-7 cells. Mol Cell Endocrinol 244, 20-30.

Borders (1985). CAPEG Database V1.2 and User Guide, External Scientific Report: Identification of cumulative assessment groups of pesticides. http://www.efsa.europa.eu/en/supporting/ pub/269e.htm (accessed 05.11.2012).

Chandler, K. J., Barrier, M., Jeffay, S., et al. (2011). Evaluation of 309 environmental chemicals using a mouse embryonic stem cell adherent cell differentiation and cytotoxicity assay. PloS One 6, e18540.

Cozens, D. D. (1982). The effect of BTS 40542 on reproductive function of multiple generations in the rat. Draft Assessment Report. Initial risk assessment report provided by rappoteur member state Ireland for the existing active substance PROCHLORAZ of the third stage (part B) of the review programme referred to in Article 8(2) of Council Directive 91/414/EEC 
Cummings, A. M., Hedge, J. L., and Laskey, J. (1997). Ketoconazole impairs early pregnancy and the decidual cell response via alterations in ovarian function. Fundam Appl Toxicol 40, 238-246.

Danielsson, B. R., Danielsson, C., and Nilsson, M. F. (2007). Embryonic cardiac arrhythmia and generation of reactive oxygen species: common teratogenic mechanism for IKr blocking drugs. Reprod Toxicol 24, 42-56.

de Castro, V. L. and Maia, A. H. (2012). Prenatal epoxiconazole exposure effects on rat postnatal development. Birth Defects Res B Dev Reprod Toxicol 95, 123-129.

de Jong, E., Barenys, M., Hermsen, S. A., et al. (2011). Comparison of the mouse Embryonic Stem Cell Test, the rat Whole Embryo Culture and the Zebrafish Embryotoxicity Test as alternative methods for developmental toxicity testing of six 1,2,4-triazoles. Toxicol Appl Pharmacol 253, 103-111.

De Coster, R., Coene, M. C., Van Camp, C., et al. (1989). Comparative effects of ketoconazole on rat, dog and human testicular steroidogenesis. J Enzyme Inhib 2, 261-268.

Di Renzo, F., Bacchetta, R., Bizzo, A., et al. (2011). Is the amphibian X. laevis WEC a good alternative method to rodent WEC teratogenicity assay? The example of the three triazole derivative fungicides Triadimefon, Tebuconazole, Cyproconazole. Reprod Toxicol 32, 220-226.

Dmytriyeva, O., Klementiev, B., Berezin, V., et al. (2013). Prenatal prochloraz treatment significantly increases pregnancy length and reduces offspring weight but does not affect socialolfactory memory in rats. Exp Toxicol Pathol 65, 591-3.

Eiben (1987). CAPEG Database V1.2 and User Guide, External Scientific Report: Identification of cumulative assessment groups of pesticides. http://www.efsa.europa.eu/en/supporting/ pub/269e.htm (accessed 05.11.2012).

Firlit, M. G. and Schwartz, N. B. (1977). Uncoupling of vaginal opening and the first ovulation - an indication of an alteration in the pituitary-gonadal axis. Biol Reprod 16, 441-444.

Forgacs, A. L., Ding, Q., Jaremba, R. G., et al. (2012). BLTK1 murine Leydig cells: A novel steroidogenic model for evaluating the effects of reproductive and developmental toxicants. Toxicol Sci 127, 391-402.

France, J. T., Mason, J. I., Magness, R. R., et al. (1987). Ovine placental aromatase: studies of activity levels, kinetic characteristics and effects of aromatase inhibitors. J Steroid Biochem 28, 155-160.

Genschow, E., Spielmann, H., Scholz, G., et al. (2002). The ECVAM international validation study on in vitro embryotoxicity tests: results of the definitive phase and evaluation of prediction models. European Centre for the Validation of Alternative Methods. Altern Lab Anim 30, 151-176.

Genschow, E., Spielmann, H., Scholz, G., et al. (2004). Validation of the embryonic stem cell test in the international ECVAM validation study on three in vitro embryotoxicity tests. Altern Lab Anim 32, 209-244.

Giavini, E. and Menegola, E. (2010). Are azole fungicides a teratogenic risk for human conceptus? Toxicol Lett 198, 106-111.

Goetz, A. K., Ren, H., Schmid, J. E., et al. (2007). Disruption of testosterone homeostasis as a mode of action for the reproduc- tive toxicity of triazole fungicides in the male rat. Toxicol Sci 95, 227-239.

Goetz, A. K., Rockett, J. C., Ren, H., et al. (2009). Inhibition of rat and human steroidogenesis by triazole antifungals. Syst Biol Reprod Med 55, 214-226.

Hass, U., Boberg, J., Christiansen, S., et al. (2012). Adverse effects on sexual development in rat offspring after low dose exposure to a mixture of endocrine disrupting pesticides. Reprod Toxicol 34, 261-74.

Hecker, M., Newsted, J. L., Murphy, M. B., et al. (2006). Human adrenocarcinoma (H295R) cells for rapid in vitro determination of effects on steroidogenesis: hormone production. Toxicol Appl Pharmacol 217, 114-124.

Hellwig, J. and Hildebrand, B. (1989). Annex XV Dossier: Proposal for harmonised classification and labelling. Study of the prenatal toxicity of Reg. 205259 in rats after oral administration (gavage) range finding study. http://echa.europa.eu/ documents/10162/f39183f6-ef29-40ae-a274-8c1c197d5f9e (accessed 05.11.2012).

Hellwig, J. and Hildebrand, B. (1990a).Annex XV Dossier: Proposal for harmonised classification and labelling. Study of the prenatal toxicity of Reg. 205259 in rabbits after oral administration (gavage). http://echa.europa.eu/documents/10162/f39183f6ef29-40ae-a274-8c1c197d5f9e (accessed 05.11.2012).

Hellwig, J. and Hildebrand, B. (1990b). CAPEG Database V1.2 and User Guide, External Scientific Report: Identification of cumulative assessment groups of pesticides. http://www.efsa. europa.eu/en/supporting/pub/269e.htm (accessed 05.11.2012).

Hellwig, J. and Hildebrand, B. (1992). CAPEG Database V1.2 and User Guide, External Scientific Report: Identification of cumulative assessment groups of pesticides. http://www.efsa. europa.eu/en/supporting/pub/269e.htm (accessed 05.11.2012).

Heneweer, M., van den Berg, M., and Sanderson, J. T. (2004). A comparison of human $\mathrm{H} 295 \mathrm{R}$ and rat R2C cell lines as in vitro screening tools for effects on aromatase. Toxicol Lett 146, 183-194.

Hermsen, S. A., van den Brandhof, E. J., van der Ven, L. T., and Piersma, A. H. (2011). Relative embryotoxicity of two classes of chemicals in a modified zebrafish embryotoxicity test and comparison with their in vivo potencies. Toxicol In Vitro 25 , 745-753.

Higley, E. B., Newsted, J. L., Zhang, X., et al. (2010). Assessment of chemical effects on aromatase activity using the H295R cell line. Environ Sci Pollut Res Int 17, 1137-1148.

Hoberman (2005). CAPEG Database V1.2 and User Guide, External Scientific Report: Identification of cumulative assessment groups of pesticides. http://www.efsa.europa.eu/en/supporting/ pub/269e.htm (accessed 05.11.2012).

Jacobsen, P. R., Axelstad, M., and Boberg, J. (2012). Persistent developmental toxicity in rat offspring after low dose exposure to a mixture of endocrine disrupting pesticides. Reprod Toxicol 34, 237-250.

Kast-Hutcheson, K., Rider, C. V., and LeBlanc, G. A. (2001). The fungicide propiconazole interferes with embryonic development of the crustacean Daphnia magna. Environ Toxicol Chem 20, 502-509. 
Kjaerstad, M. B., et al. (2007). Effects of azole fungicides on the function of sex and thyroid hormones. Pesticides Research No. 111, Report for the Danish Environmental Protection Agency.

Kjaerstad, M. B., Taxvig, C., Andersen, H. R., et al. (2010a). Mixture effects of endocrine disrupting compounds in vitro. Int $J$ Androl 33, 425-433.

Kjaerstad, M. B., Taxvig, C., Nellemann, C., et al. (2010b). Endocrine disrupting effects in vitro of conazole antifungals used as pesticides and pharmaceuticals. Reprod Toxicol 30, 573-582.

Kragie, L., Turner, S. D., Patten, C. J., et al. (2002). Assessing pregnancy risks of azole antifungals using a high throughput aromatase inhibition assay. Endocr Res 28, 129-140.

Kucera, P., Cano, E., Honegger, P., et al. (1993). Validation of whole chick embryo cultures, whole rat embryo cultures and aggregating embryonic brain cell cultures using six pairs of coded compounds. Toxicol In Vitro 7, 785-798.

Kuske, B., Pulyanina, P. Y., and zur Nieden, N. I. (2012). Embryonic stem cell test: stem cell use in predicting developmental cardiotoxicity and osteotoxicity. Methods Mol Biol 889, 147179.

Laier, P., Metzdorff, S. B., Borch, J., et al. (2006). Mechanisms of action underlying the antiandrogenic effects of the fungicide prochloraz. Toxicol Appl Pharmacol 213, 160-171.

Lambrot, R., Muczynski, V., Lecureuil, C., et al. (2009). Phthalates impair germ cell development in the human fetal testis in vitro without change in testosterone production. Environ Health Perspect 117, 32-37.

Laville, N., Balaguer, P., Brion, F., et al. (2006). Modulation of aromatase activity and mRNA by various selected pesticides in the human choriocarcinoma JEG-3 cell line. Toxicology 228, 98-108.

Long, M., Laier, P., Vinggaard, A. M., et al. (2003). Effects of currently used pesticides in the AhR-CALUX assay: comparison between the human TV101L and the rat H4IIE cell line. Toxicology 194, 77-93.

Marcsisin (1987). CAPEG Database V1.2 and User Guide, External Scientific Report: Identification of cumulative assessment groups of pesticides. http://www.efsa.europa.eu/en/supporting/ pub/269e.htm (accessed 05.11.2012).

Marotta, F. and Tiboni, G. M. (2010). Molecular aspects of azolesinduced teratogenesis. Expert Opinion On Drug Metabolism And Toxicology 6, 461-482.

Marx-Stoelting, P., Adriaens, E., Ahr, H. J., et al. (2009). A review of the implementation of the embryonic stem cell test (EST). The report and recommendations of an ECVAM/ReProTect Workshop. Altern Lab Anim 37, 313-328.

Mason, J. I., Murry, B. A., Olcott, M., et al. (1985). Imidazole antimycotics: inhibitors of steroid aromatase. Biochem Pharmacol 34, 1087-1092.

Mason, J. I., Carr, B. R., and Murry, B. A. (1987). Imidazole antimycotics: selective inhibitors of steroid aromatization and progesterone hydroxylation. Steroids 50, 179-189.

Menegola, E., Broccia, M. L., Di Renzo, F., et al. (2006). Dysmorphogenic effects of some fungicides derived from the imidazole on rat embryos cultured in vitro. Reprod Toxicol 21, 74-82.
Mineshima, H., Fukuta, T., Kato, E., et al. (2012). Malformation spectrum induced by ketoconazole after single administration to pregnant rats during the critical period - comparison with vitamin A-induced malformation spectrum. J Appl Toxicol 32, 98-107.

Moser, V. C., Barone, S. Jr., Smialowicz, R. J., et al. (2001). The effects of perinatal tebuconazole exposure on adult neurological, immunological, and reproductive function in rats. Toxicol Sci 62, 339-352.

Muilerman, H., Daniel, L., and Pinzauti, I. (2012). PAN Europe challenges Commission in Court on pesticide prochloraz. http://www.endseurope.com/docs/120502a.pdf (accessed 09.08.2012).

Nielsen, F. K., Hansen, C. H., Fey, J. A., et al. (2012). H295R cells as a model for steroidogenic disruption: a broader perspective using simultaneous chemical analysis of 7 key steroid hormones. Toxicol In Vitro 26, 343-350.

Noriega, N. C., Ostby, J., Lambright, C., et al. (2005). Late gestational exposure to the fungicide prochloraz delays the onset of parturition and causes reproductive malformations in male but not female rat offspring. Biol Reprod 72, 1324-1335.

Ohlsson, A., Cedergreen, N., Oskarsson, A., et al. (2010). Mixture effects of imidazole fungicides on cortisol and aldosterone secretion in human adrenocortical H295R cells. Toxicology 275, 21-28.

Ohno, K., Araki, N., Yanase, T., et al. (2004). A novel nonradioactive method for measuring aromatase activity using a human ovarian granulosa-like tumor cell line and an estrone ELISA. Toxicol Sci 82, 443-450.

Pont, A., Williams, P. L., Azhar, S., et al. (1982). Ketoconazole blocks testosterone synthesis. Arch Intern Med 142, 2137 2140 .

Raab (1986). CAPEG Database V1.2 and User Guide, External Scientific Report: Identification of cumulative assessment groups of pesticides. http://www.efsa.europa.eu/en/supporting/ pub/269e.htm (accessed 05.11.2012).

Riebeling, C., Schlechter, K., Buesen, R., et al. (2011). Defined culture medium for stem cell differentiation: applicability of serum-free conditions in the mouse embryonic stem cell test. Toxicol In Vitro 25, 914-921.

Rijk, J. C., Peijnenburg, A. A., Blokland, M. H., et al. (2012). Screening for modulatory effects on steroidogenesis using the human H295R adrenocortical cell line: A metabolomics approach. Chem Res Toxicol 25, 1720-1731.

Rockett, J. C., Narotsky, M. G., Thompson, K. E., et al. (2006). Effect of conazole fungicides on reproductive development in the female rat. Reprod Toxicol 22, 647-658.

Sanderson, J. T., Boerma, J., Lansbergen, G. W., et al. (2002). Induction and inhibition of aromatase (CYP19) activity by various classes of pesticides in H295R human adrenocortical carcinoma cells. Toxicol Appl Pharmacol 182, 44-54.

Schneider, S. (2001). Annex XV Dossier: Proposal for harmonised classification and labelling. BAS $480 \mathrm{~F}$ - Maternal toxicity study in Wistar rats - Oral administration (gavage). http:// echa.europa.eu/documents/10162/f39183f6-ef29-40ae-a2748c1c197d5f9e (accessed 05.11.2012). 
Schneider, S. (2002). Annex XV Dossier: Proposal for harmonised classification and labelling. BAS $480 \mathrm{~F}$ - Prenatal developmental toxicity study in Wistar rats - Oral administration (gavage). http:/echa.europa.eu/documents/10162/f39183f6-ef29-40aea274-8c1c197d5f9e (accessed 05.11.2012).

Schurmeyer, T. and Nieschlag, E. (1984). Effect of ketoconazole and other imidazole fungicides on testosterone biosynthesis. Acta Endocrinol (Copenh) 105, 275-280.

Seiler, A. E., Buesen, R., Visan, A., et al. (2006). Use of murine embryonic stem cells in embryotoxicity assays: the embryonic stem cell test. Methods Mol Biol 329, 371-395.

Seiler, A. E. and Spielmann, H. (2011). The validated embryonic stem cell test to predict embryotoxicity in vitro. Nat Protoc 6, 961-978.

Stresser, D. M., Turner, S. D., McNamara, J., et al . (2000). A highthroughput screen to identify inhibitors of aromatase (CYP19). Anal Biochem 284, 427-430.

Stummann, T. C., Hareng, L., and Bremer, S. (2008). Embryotoxicity hazard assessment of cadmium and arsenic compounds using embryonic stem cells. Toxicology 252, 118-122.

Sung, D. J., Kim, J. G., Won, K. J., et al. (2012). Blockade of $\mathrm{K}^{+}$ and $\mathrm{Ca}^{2+}$ channels by azole antifungal agents in neonatal rat ventricular myocytes. Biol Pharm Bull 35, 1469-1475.

Takeuchi, S., Iida, M., Yabushita, H., et al. (2008). In vitro screening for aryl hydrocarbon receptor agonistic activity in 200 pesticides using a highly sensitive reporter cell line, DR-EcoScreen cells, and in vivo mouse liver cytochrome P450-1A induction by propanil, diuron and linuron. Chemosphere 74, 155-165.

Taxvig, C., Hass, U., Axelstad, M., et al. (2007). Endocrine-disrupting activities in vivo of the fungicides tebuconazole and epoxiconazole. Toxicol Sci 100, 464-473.

Taxvig, C., Vinggaard, A. M., Hass, U., et al. (2008). Endocrinedisrupting properties in vivo of widely used azole fungicides. Int $J$ Androl 31, 170-177.

Toung (2005). CAPEG Database V1.2 and User Guide, External Scientific Report: Identification of cumulative assessment groups of pesticides. http://www.efsa.europa.eu/en/supporting/ pub/269e.htm (accessed 05.11.2012).

Trosken, E. R., Scholz, K., Lutz, R. W., et al. (2004). Comparative assessment of the inhibition of recombinant human CYP19 (aromatase) by azoles used in agriculture and as drugs for humans. Endocr Res 30, 387-394.

Trosken, E. R., Fischer, K., Volkel, W., et al. (2006). Inhibition of human CYP19 by azoles used as antifungal agents and aromatase inhibitors, using a new LC-MS/MS method for the analysis of estradiol product formation. Toxicology 219, 33-40.

van Dartel, D. A., Pennings, J. L., de la Fonteyne, L. J., et al. (2011). Concentration-dependent gene expression responses to flusilazole in embryonic stem cell differentiation cultures. Toxicol Appl Pharmacol 251, 110-118.
Villeneuve, D. L., Ankley, G. T., Makynen, E. A., et al. (2007). Comparison of fathead minnow ovary explant and H295R cellbased steroidogenesis assays for identifying endocrine-active chemicals. Ecotoxicol Environ Saf 68, 20-32.

Vinggaard, A. M., Hnida, C., Breinholt, V., et al. (2000). Screening of selected pesticides for inhibition of CYP19 aromatase activity in vitro. Toxicol In Vitro 14, 227-234.

Vinggaard, A. M., Nellemann, C., Dalgaard, M., et al. (2002). Antiandrogenic effects in vitro and in vivo of the fungicide prochloraz. Toxicol Sci 69, 344-353.

Vinggaard, A. M., Christiansen, S., Laier, P., et al. (2005). Perinatal exposure to the fungicide prochloraz feminizes the male rat offspring. Toxicol Sci 85, 886-897.

Vinggaard, A. M., Niemela, J., Wedebye, E. B., et al. (2008). Screening of 397 chemicals and development of a quantitative structure - activity relationship model for androgen receptor antagonism. Chem Res Toxicol 21, 813-823.

Wahle (2004). CAPEG Database V1.2 and User Guide, External Scientific Report: Identification of cumulative assessment groups of pesticides. http://www.efsa.europa.eu/en/supporting/ pub/269e.htm (accessed 05.11.2012).

West, P. R., Weir, A. M., Smith, A. M., et al. (2010). Predicting human developmental toxicity of pharmaceuticals using human embryonic stem cells and metabolomics. Toxicol Appl Pharmacol 247, 18-27.

Wilson, V. S., Lambright, C., Furr, J., et al. (2004). Phthalate esterinduced gubernacular lesions are associated with reduced insl3 gene expression in the fetal rat testis. Toxicol Lett 146, 207-215.

Wuttke, W. (2001). Effects of BAS $480 \mathrm{~F}$ on the aromatase activity in cultivated human and rat granulosa cells. Georg-AugustUniversität, Göttingen, Germany Fed. Rep. unpublished BASF DocID 2001/1017365

\section{Acknowledgement}

The Ministry of Food, Agriculture and Fisheries of Denmark and the Danish Veterinary and Food Administration are acknowledged for their financial support. We are indebted to Dorte Lykkegaard Korsbech and Birgitte Møller Plesning for excellent technical assistance.

\section{Correspondence to}

Anne Marie Vinggaard, PhD

National Food Institute

Technical University of Denmark

Mørkhøj Bygade 19

2860 Søborg

Denmark

e-mail: annv@food.dtu.dk 